\title{
Teamwork in nursing: restricted to nursing professionals or an interprofessional collaboration?*
}

\author{
Trabalho em equipe de enfermagem: circunscrito à profissão \\ ou colaboração interprofissional?? \\ Trabajo en equipo de enfermería: circunscrito a la profesión \\ o colaboración interprofesional
}

Geisa Colebrusco de Souza ${ }^{1}$, Marina Peduzzi², Jaqueline Alcântara Marcelino da Silva ${ }^{1,3}$, Brígida Gimenez Carvalho ${ }^{1,4}$

\begin{abstract}
How to cite this article:
Souza GC, Peduzzi M, Silva JAM, Carvalho BG. Teamwork in nursing: restricted to nursing professionals or an interprofessional collaboration. Rev Esc
\end{abstract} Enferm USP. 2016;50(4):640-647. DOI: http://dx.doi.org/10.1590/S0080-623420160000500015

\footnotetext{
* Extracted from the dissertation: "Trabalho em equipe de enfermagem: interação, conflito e ação interprofissional em hospital especializado", Escola de Enfermagem, Universidade de São Paulo, 2011.

${ }^{1}$ Universidade de São Paulo, Escola de Enfermagem, Programa de PósGraduação em Gerenciamento em Enfermagem, São Paulo, SP, Brazil.

${ }^{2}$ Universidade de São Paulo, Escola de Enfermagem, Departamento de Orientação Profissional, São Paulo, SP, Brazil.

${ }^{3}$ Universidade Federal de São Carlos, Departamento de Enfermagem, São Carlos, SP, Brazil.

${ }^{4}$ Universidade Estadual de Londrina, Departamento de Saúde Coletiva, Londrina, PR, Brazil.
}

\begin{abstract}
Objective: To understand the nursing professionals' conceptions of teamwork and their elements. Method: A qualitative study conducted in an oncological hospital using a semistructured interview with 21 nursing professionals. Results: Two conceptions emerged from the accounts: teamwork restricted to nursing professionals and teamwork with interprofessional collaboration with particular importance for interactive dimensions: communication, trust and professional bonds, mutual respect and recognition of the other's work, collaboration, and conflict, with this last subcategory considered as an obstacle to teamwork. Conclusion: Nursing conceives teamwork as an interprofessional practice, which is a result of the quality of interaction among professionals from different areas and involves the recognition and handling of conflicts.
\end{abstract}

\section{DESCRIPTORS}

Nursing; Work; Nursing, Team; Interprofessional Relations.
Corresponding author:

Geisa Colebrusco de Souza

Av. Dr. Enéas de Carvalho Aguiar, 419

05403-000 - São Paulo, SP, Brazil

geisacole@usp.br
Received: 04/04/2016

Approved: 07/20/2016 


\section{INTRODUCTION}

Teamwork in healthcare is a way to organize the practices for a broad approach to health needs, from the perspective of comprehensiveness as considered by the Unified Health System (SUS - Sistema Único de Saúde), from the Brazilian government, and it requires changes in the healthcare models ${ }^{(1)}$. Accomplishing interprofessional collaborative teamwork is essential for healthcare quality, safety and patient and job satisfaction ${ }^{(2-3)}$. However, there is no consensus on the concept of teamwork and interprofessional collaboration, the abilities it involves and how to measure its effectiveness ${ }^{(2,4)}$. Most studies focus on these dimensions and characteristics: interaction; communication; articulation of actions; mutual respect; trust; recognition of professional roles; collaboration; common goals; patient-centered care. The purpose of these dimensions are health needs of the patients ${ }^{(1-2,5-7)}$.

Initial discussions on teamwork in nursing date back to 1950 and aimed to reduce care fragmentation and problems due to scarcity of staff( ${ }^{(8)}$. Although this proposal promoted full care, the practice remained fragmented between the planning of a nurse's assignment and its execution, because such care was delegated to nursing aides and technicians ${ }^{(9)}$.

In this study, to understand the interactions from teamwork in nursing, a theoretical board was built, based on the studies addressing work processes in healthcare and nursing ${ }^{(10)}$, These studies were Jürgen Habermas' concepts of communicative and instrumental actions ${ }^{(11)}$ and Axel Honneth's concept of recognition ${ }^{(12)}$. The approach adopted in this study assumes an interface between work and social interaction. On the one hand, work is analyzed as a productive action based on technical rules and, on the other hand, as an interaction and a communicative action whose purpose is the understanding between subjects ${ }^{(10-11)}$.

Interaction and communication, recognized as fundamental for teamwork development ${ }^{(5,7)}$, can be analyzed according to the concepts of Habermas' rationalities: communicative actions to formulate and achieve a result favoring understanding; instrumental actions seeking to ensure success previously defined actions based on technical rules ${ }^{(11)}$.

In communicative practice, interactions seeking understanding are based on three expectations of speech validity that the interlocutors expect to be shared between them: propositional truth (observed when matching speech to facts seen in reality), normative correction (refers to the sphere of ethics, social values and norms), and expressive authenticity (corresponding to the subjectivity of interlocutors, trust and sincerity expressed in intersubjective relations) $)^{(11)}$.

However, the interaction among professionals in teams do not always lead to understanding, and in fact, sometimes triggers conflicts. A conflict can express positive or negative meanings, depending on how they occur and are conducted. In this study, the understanding of conflict is based on a triad: self-confidence; self-respect; and self-esteem; which refer to the spheres of love, rights and solidarity, respectively. From this perspective, conflicts express a lowered status: mistreatment and violation; deprivation of rights, exclusion; degradation and offense. Non-recognition or the presence of disrespect is the driving force for conflicts ${ }^{(12-14)}$.

Based on the relevance of teamwork for healthcare and nursing and the persistent lack of consensus on this theme, this study was conducted in a specialized hospital service aiming to understand the conceptions of nursing professionals regarding teamwork and their components.

\section{METHOD}

This study used a qualitative approach, which is recommended to investigate social phenomena ${ }^{(15)}$, such as the perception and conception of teamwork from nursing professionals.

This study was conducted in a public hospital managed by the Social Health Organization, specialized in oncology, and located in the city of São Paulo. Data were collected in two divisions: clinical surgery (CS) hospitalization and ambulatory specialties (AS), as recommended by the nursing department managers. Semi-structured interviews were conducted with 21 nursing professionals selected through snowball sampling ${ }^{(16)}$ - starting with the coordinators of hospital divisions, who recruited a nurse and a nursing technician, who, successively, recruited another colleague from the same professional category. The selection of participants took into account the intentionality and significant connection with the theme, based on the request for recruitment of a professional who could provide a report on the theme of this study, with equal participation of the professional categories. This study used a criterion of saturation, when the investigator recognized that the participant had already understood the underlying logic of the studied group based on the study objectives ${ }^{(15,17)}$.

Three nurse managers, nine registered nurses and nine nursing technicians were interviewed between April and June 2010, during working hours, totaling 20 hours of fully transcribed recordings. Quotations were identified according to category codes: $(\mathrm{N})$ for nurses and $(\mathrm{NT})$ nursing technicians.

An interview guide was used with the profile of participants which included: sex, age, professional category, educational attainment, professional training, length of service in the institution and current division. Guiding questions related to actions performed with other professionals, perceptions of collective work/teamwork and full care and care comprehensiveness were asked.

An interview content analysis was conducted ${ }^{(18)}$ using the concepts of teamwork, interprofessional collaboration, work processes in healthcare and nursing, communication action, instrumental action and concepts of recognition.

In the analysis, a general reading was conducted to formulate assumptions according to the study objective $e^{(15,18)}$. Then, each interview was read to recognize its particularities and set up the core meanings that emerged from the accounts. For raw text processing, accounts were cut out into units of meanings, and a synthesis of each interview was built. Lastly, a cross-sectional analysis was conducted by division (CS and AS) and by professional category ( $\mathrm{N}$ and NT), seeking to bring out similarities, contradictions and antagonisms present in interviews considering the theoretical framework ${ }^{(15)}$. 
This study observed the ethical principles of the resolution issued by the National Health Council (466/2012), obtained the approval of the Research Ethics Committee (CAAE - 0039.0.196.00009) and had consent from those in charge of the institution and the participants.

\section{RESULTS}

The interviewed nursing professionals were female, mean age: 28 years (24-35 years), mean time of graduation: 5 years (2-10 years), mean length of service in the hospital: 14 months (5-24 months) and in the current division: 11 months (5-17 months). Working hours of participants ranged from 40 hours in AS and 36 or 40 hours a week in $\mathrm{CS}$, depending on the function.

Considering the theoretical reference, two categories were defined: teamwork, which had two subcategories: as an interprofessional action and teamwork restricted to nursing professionals. The second category was the interactive dimension of teamwork, with five subcategories: communication, trust and professional bonds, mutual respect and recognition of the other's work, collaboration and conflict. The cross-sectional analysis by division and professional category did not present significant differences; the results refer to interviews in general, except for collaboration and conflict, due to the differences identified.

\section{TEAMWORK IN NURSING AS AN INTERPROFESSIONAL PRACTICE}

Most accounts showed the conception of teamwork in nursing that includes interprofessional actions. For most interviewees, teamwork is not restricted to nursing professionals, since they interact with professionals from other areas in their daily routine of patient care:

Teamwork (...) is not restricted to us (nursing professionals), nurses can go to a certain extent, but in a certain moment, a nurse cannot find the family member of a patient to provide patient discharge directions, then, who should I call? Then, I contact another professional from social service (...) teamwork is not restricted to us - nurses and nursing technicians -, there's a group of professionals involved, who helps us a lot (N11 - CS).

Teamwork, ah, it involves several professionals, from the same category or not, in which the evaluation of each one is very important to the whole group (N1-AS).

The interviewees referred to the performance of actions and knowledge of professionals from other areas to resolve health issues of patients. The accounts showed they recognize complementariness, interdependence and limits of several professions while providing care.

\section{TEAMWORK RESTRICTED TO NURSING PROFESSIONALS}

Professionals from both divisions referred to teamwork restricted to the nursing staff. The interviewees indicated the following needs: communication, connection between the two categories and sharing a common goal:

The nursing team, (...) everyone has a goal which is to provide the best care to the patient, (...) this teamwork will be segmented, each professional will have his/her own functions, a nurse has his/her functions there, some things are specific to nurses and technicians, so each one will perform one's activities, ensuring communication, connection, interaction, then we will be able to achieve the same goal (N14 - CS).

The interviewees from CS expressed a feeble connection between nurses and nursing technicians for patient care decisions and directions. Their interviews showed that the integration of actions is infrequent, but encouraged by the coordinators:

The importance of teamwork is considered as a whole, that is, one helping the other, from nurses to technicians, because nursing is not recognized as having united professionals (...) I would like to see nursing professionals, technicians and nurses closer, working together, (...) then, I think it's interesting that in this division the coordinator always highlights that, teamwork should be practiced, there shouldn't be any difference between technicians and nurses, neither from nurses to technicians (NT21 - CS).

Unshared decision-making processes impair co-responsibility. In the excerpt below, a nursing technician explained how she attributes the responsibility for actions if they are assigned in a centralized manner:

Nurses are like a mirror to us; then, when we need something, who do we refer to? We talk to a nurse; and if she says something wrong, it's not our fault, it's the nurse's fault, then, we have this thing to defend us (NT12 - CS).

\section{INTERACTIVE DIMENSION OF TEAMWORK}

The accounts of these professionals showed that communication, trust and professional bond, mutual respect, recognition of the other's work and collaboration are elements of teamwork, and that conflicts are an obstacle to it.

\section{COMMUNicATION}

Communication is considered a bridge for the other elements, since trust, professional bond, mutual respect, recognition of the other's work and collaboration are built through it. In both divisions, the interviewees highlighted communication as inherent to teamwork. The analysis showed two conceptions of communication: one with a predominance for the search for agreements and consensus, characterized as a communicative action, and the other characterized as instrumental communication, with a predominance of exchange of information that is almost impersonal, but indispensable, considering that its absence would not allow the professionals to perform technical procedures:

Then, we make this question of communication and interaction very clear, at the end of the shift, look, you're with me as a technician, let's close our shift, before we transfer it, how was it? Ah, I released the drain, we had expenses, closings, and that's what I mean in terms of communication, I think communication is critical, it has to be present (N11 - CS).

\section{TRUST AND PROFESSIONAL BONDS}

Building trust and professional bonds between team professionals depends on whether communication is based 
on communicative action or instrumental-strategic action. Nursing technicians emphasized the need to win the trust of the nurses in their work. However, they did not mention anything about the opposite, which meant that nurses also needed to win the trust of the technicians since social interaction is a two-way path:

A nurse has to trust the nursing technician, (...) then, the relation between a nurse and a nursing technician has to be based on trust; otherwise, it's impossible to work; there's no point in assigning a task to a nursing technician if I, as a nurse, don't trust him and has to check everything he's doing (NT5 - AS).

Trust and professional bonds in the team were also related to the joint length of service; the interviewees said that building trust and bonds requires positive joint experiences, shared work experiences, according to the account below:

Sometimes, they (nursing technicians) are in doubt, as a new nurse is coming to the division, they don't know what to do, they are a little insecure, or they don't feel free to ask or do what the new nurse is asking, but it's because there is no interaction, they still don't know how to work (N14 - CS).

\section{Mutual RESPECT AND WORK RECOGNITION}

Another element of teamwork - mutual respect and recognition of each other's work - can be built through worker participation in expressing his/her opinion and suggesting alternatives. Knowledge complementariness in patient care requires the recognition of the work performed by the other professionals:

There should be work interaction, (...) if there's no active participation, there's no working together, opinion exchange, no speaking out, I guess it's also important to make things work out, to build reliability (...). Interaction, when we mean it, refers to being open to what other professionals have to say (N8 - AS).

I guess respect is very important, because other things are built on respect, with time, knowing that a colleague's opinion is important, recognizing a colleague's background, the experiences he/she has and is sharing with you, (...) it's totally related to respect; for you to work, for you to be part of a team, that's it (NT6 - AS).

The subcategories 'collaboration' and 'conflict' were analyzed separately between the divisions, due to the considerable differences identified.

\section{Collaboration}

The accounts provided by the nursing professionals working in AS showed a conception of teamwork that includes collaboration as an acceptance of the other's participation when reaching for agreements involving different nursing categories:

Also with (name of coordinator), we seek to develop teamwork, she asks things to us, we perform it in the best way possible, we give her many ideas too, about what can be improved, ideas we have in our practice (...), then we try to work together, there's no special order, and we perform it there, and that's all, we also give ideas (N9 - AS).
The interviewees mentioned a nuance in teamwork collaboration expressed as the availability to help a colleague when difficulties were recognized while performing the procedures.

The accounts from AS staff showed collaboration was present between peers, between professionals from the same category, and between both categories, for two different reasons, for reaching consensuses and for complementariness of the technical dimension of care practices. The latter is expressed in the quotation below:

With nursing technicians, we frequently work in collaboration, when I heparinize a portocath, for example, there's always one of them with me, they help with the materials, with everything, they're always there, and they're also interested in learning, they observe and have initiative to help, the team is already this way, you don't need to call them (...) for wound dressings too, when they are doing it, I check and participate, and among them, they belp each other (N9-AS).

Unlike the accounts from AS staff, nursing technicians from CS said collaboration occurs predominantly between nursing technicians. Nurses participate only in specific and private procedures:

Few activities are performed with the nurse, it's more for things that we, technicians, don't do, the procedures, which is the vesical catheter cleansing, then, to prevent contamination, then they ask us to help them, another activity is to insert the vesical catheter delay, some of them don't like to do it by themselves, and it's faster with some help, for nasoenteral catheter too, when used (NT21 - CA).

\section{Conflict}

Conflict appeared as an obstacle to teamwork, and it assumed two forms: inter-group (between two different teams) and intra-group (in the same team) conflicts. Intragroup conflicts were further subdivided in two: between peers (in the same professional category) or between categories (between nurses and nursing technicians).

In AS, most conflicts occurred between different teams of the hospital, as a result of divergences regarding patient therapy:

One day, I stayed in the hospital until 10 pm to help insert an epidural catheter in a patient (...) and the nurse (from another team) was not interested in the procedure (...). Then, it was a great stress because the doctor (from the interviewee's team) (...) said it was necessary to insert the catheter! Then I talked (...) to the anesthetist, the anesthetist on duty said: No, I won't insert it! (...) on the third time, I said I wouldn't do it because (...) it was something about teamwork, the doctor (from the interviewee's team) came from home just to insert the catheter, but there were two doctors on duty, and I then I stayed here (...) then, on this day, I stayed here until $10 \mathrm{~h} 30 \mathrm{pm}$, but was it under my responsibility? No! Wouldn't the patient be assisted? In theory, yes, because the nursing staff works 24 hours a day, but on that moment, I thought it was important to stay (N1 - AS).

In AS, conflicts also occurred between peers, nursing technicians and nurses, due to the arrival of a new professional to work in the team. Shorter time performing joint 
work and lack of trust and recognition may have caused these conflicts:

I've had many divergences with a nursing technician here, with (name of NT), (...) she came from another place, she didn't have the knowledge I already had, although I had worked in a similar area, (...) she is slow, not talkative, and I'm very active, I talk to everyone, (...) I don't feel shy to ask things to other people, but she does, then, with time, now after some time, we've improved a lot, but it was hard in the beginning, then, we have to learn how to accept what is different (NT4-AS).

Unlike AS, most conflicts in CS were intra-group conflicts and between the categories (i.e., between nurses and nursing technicians). As highlighted in the quotation, unequal insertion of these workers was observed in the work process based on the technical training, as well as a rigorous division of work, in which nurses refuse to perform less complex actions.

We call the nurse for care, she's a registered nurse, but many times, she refuses to help, she runs away, (...) most people think it's her function to sit, adjust a prescription, it's to promote evolution, it's to take the sheet with our notes and make a prescription! For her evolution, and I think that's not what happens! Then, we call the nurse for care, (...) to watch the patient, check the dressing (...). We frequently call the nurse, you know? For the team! To work with us (NT12 - CS).

For the nursing technicians, the conflicts occurred due to lack of collaboration between nurses in activities of low technical complexity, such as transferring a patient to a stretcher and taking him to the toilet, activities not recognized by nurses as part of their assignments.

\section{DISCUSSION}

In the last decade, teamwork started to be defined as an interprofessional collaborative practice, in terms of a formalized team, with the collaboration of professionals from different areas for patient-centered care ${ }^{(19-20)}$. Most interviewees cited this type of work organization in this recent definition, with nursing professionals being one of the groups comprising the interprofessional team, but they also mentioned the conception of teamwork restricted to nursing professionals only.

A recent review highlighted nursing as the most frequently mentioned profession in studies about interprofessional collaborative practice and interprofessional education ${ }^{(2)}$. This reinforces the understanding of its central role of mediation in relation to other professions in the health area ${ }^{(2,19)}$. The results of this study also indicated that nurses were a part of a team of several healthcare professionals and their contribution to patient-centered care, while at the same time they overlooked basic services, as observed in the account that prioritized the catheter insertion when providing for the patient's needs. In addition, studies show nurses are recognized as agents of convergence and distribution of information ${ }^{(21)}$, who have power in interprofessional relations ${ }^{(6)}$.

Complementariness of actions was identified in the accounts related to the interprofessional team and the team restricted to nursing professionals. Differences were highlighted in the technical dimension of work among nurses, nutritionists and physicians, as were the differences between nurses and nursing technicians, which meant that the actions of one professional did not invalidate the action of the other. In the division of work in the health area, specialized actions are complementary and expand complex responses to healthcare needs. Team integration does not invalidate technical differences, it seeks to co-ordinate the actions and interaction between subjects ${ }^{(22)}$.

Although nurses mentioned interaction with nursing technicians in teamwork, performing procedures with no interaction and effective communication about the actions was especially noticed in the technical dimension ${ }^{(23)}$. This confirmed the usual technical division of work in the nursing area ${ }^{(9)}$, and was indicative of a work organization that is different from integrated and collaborative teamwork.

In the interviews, bonding and respect were indicated as elements of teamwork. The interviewees highlighted the lack of integration between nurses and nursing technicians and the absence of nursing technicians in the decisionmaking processes, which impaired co-responsibility. The results do not show the dynamics of collaborative teams that rely on interaction, respect, bonding and shared decision making processes ${ }^{(19,23-24)}$. By creating opportunities to express subjectivity based on communication, respect and acceptance of differences, it is possible to promote jointdecision making. This process fosters joint responsibility of final work objectives and the organization of teams in a less hierarchical and fragmented manner ${ }^{(24)}$.

When referring to collaborative teamwork, the attribute most often mentioned was communication. It was considered as the means in building the other elements of collaborative practice. This result is in agreement with studies in which communication is considered critical for negotiation and the construction of professional bonds and trust ${ }^{(19,23,25)}$. In both conceptions of teamwork, as an interprofessional practice in nursing and that which is restricted to the nursing staff, communicative action, based on dialogue, allows professionals to develop collaboration. However, this communication is many times restricted to instrumental logic, used only for the transfer of information.

With Habermas' theoretical approach ${ }^{(11)}$, the logic that guides the actions in healthcare is analyzed, questioning when these actions exclusively refer to techniques, qualifying it as an instrumental action. This study identified two logical interpretations in the interaction and communication among the professionals: the communicative logic, which referred to the contributions from other professionals, and instrumental logic, restricted to procedure information transfer ${ }^{(11)}$.

Fulfilling healthcare needs requires a balance between these two kinds of logic, with communicative action promoting understanding and instrumental action pointing away from moments of dialogue and agreement ${ }^{(10)}$. Professionals have to recognize moments which should be based on dialogue and they should consider the patient, the family and the nursing technicians at these times.

The elements from the interactive dimension of teamwork mentioned by the participants: communication; trust; mutual respect; shared decision making; collaboration; healthcare coordination; recognition of nursing staff roles; confirm the 
characteristics of teamwork from studies on this theme $\mathrm{e}^{(1,5,19,23,25)}$.

The element of respect mentioned in the interviews can be interpreted using the concepts from the theory of recognition (12). The respect that one obtains from his/her peers is related to being recognized by workers and patients in the sphere of solidarity, in the recognition of his/her participation in work, and lastly, his/her individual particularities and abilities ${ }^{(14)}$.

Regarding collaboration, the availability to collaborate with another professional is essentially voluntary, a characteristic indicated in the interviews and which has an impact on teamwork. Collaboration should not be supported only by the goodwill of professionals, it also requires institutional and governmental support to make it viable ${ }^{(5)}$. The opportunity to collaborate was presented at moments when the interviewees recognized that another professional needed help to perform technical procedures. However, collaboration was also mentioned in the logic of consensus construction, that is, in communicative action. Complex approaches require interaction among professionals, the patient and the family. They are beneficial when their instrumental and communicative logic is present, that is, when instrumental action is replaced at times that require communicative action ${ }^{(11)}$.

The results also show situations of conflict considered negatively by the interviewees, which may be obstacles to collaborative teamwork. The origins of conflicts in this study were: divergences regarding the patient therapy, arrival of new professionals, lack of collaboration, non-recognition of the other's work and disagreements in the divisions of activities performed between nurses and nursing technicians in work shifts.

The conflict reported by the nurse about the catheter insertion in a patient was an instance of inter-group conflict, with divergences regarding the patient therapy, configuring a situation of disrespect in the sphere of rights, according to the concepts from the theory of recognition ${ }^{(12)}$. Obligations were not fulfilled regarding the patient and the professionals from the team in charge of the patient. Any non-compliance with these obligations related to the other workers affects operations in the division, care comprehensiveness and workload distribution, considering that some assume work that should be performed by others.

The conflict due to the arrival of new professionals in the team was presented as individual differences, lack of affinity due to new work relations resulting in fragile professional bonds and trust, combined with situations of disrespect, non-recognition of the others'value and capability. In these cases, nursing technicians and recently-admitted nurses did not have their personal and professional abilities recognized by their peers, depriving them of the possibility to add social value to their work.

To achieve successful relations in the sphere of solidarity, a subject depends on the intersubjective recognition of his/her abilities and achievements, leading to social and self-esteem based on the value assigned to their tangible characteristics ${ }^{(12)}$.

The interviewees from the division of CS highlighted conflicts between nursing technicians and nurses due to the absence of nurses in the procedures of low complexity, which does not conform to the idea of being available to collaborate and recognize the other person's work. When a nurse refuses to perform activities usually assigned to nursing technicians, this nurse expresses low appreciation of such work and degrades the value of the nursing technicians, as less complex actions are usually considered of low social value.

In this situation, conflict also expresses the contradictions between the social and technical division of work between nursing technicians and nurses, which were also found in a study that analyzed conflicts between managers and workers from a basic healthcare unit. The studies also found lack of collaboration in the workplace and the presence of disrespect in asymmetrical relationships ${ }^{(14)}$.

Based on the concept of recognition ${ }^{(12)}$, one can conclude that, in the work relations of the interviewees, conflicts were mainly caused by the fight for recognition in the sphere of social esteem. Teamwork in healthcare presents a potential to promote intersubjective recognition and collaborative work $^{(13)}$; otherwise, it may lead to conflicts, as analyzed in this study.

\section{CONCLUSION}

The results of this study showed, above all, the conception of teamwork in the nursing area as an interprofessional practice. The perception of nursing professionals as one of the groups that constitute the team was predominant, with no professional isolation, and the nurse's capability to combine healthcare with other areas and professional categories and prioritize patient-centered care was noted. However, some interviewees mentioned teamwork restricted to nursing.

Interprofessional teamwork and also teamwork restricted to nursing highlighted the elements that qualify it. They were; communication, trust, professional bond, mutual respect, recognition of the others' work, and collaboration, as well as conflict, indicated as an obstacle to intra-group and inter-group integration and collaboration.

Communication was understood as a bridge to the other teamwork attributes. Communicative rationality is a means to build trust, professional bonds, mutual respect, recognition of the other's work and collaboration. However, the results show that in some actions, instrumental actions affected some healthcare aspects that required communicative actions. In healthcare, these dimensions have to be balanced, without a predominance of one dimension over another.

In nursing, unshared decision-making processes impair co-responsibility between nurses and nursing technicians due to the fact that nurses control decisions in nursing practices.

Conflicts occurred between teams of various sectors or specialties (inter-group conflicts) or between members of the same team (intra-group conflicts). The origins of conflicts were: divergences regarding patient care priority, arrival of new professionals in the team, lack of trust, nonrecognition of the other's work, and lack of collaboration in patient assistance.

The limitations of this study are related to the exclusive participation of nursing professionals, and imply the development of studies with professionals from other 
areas, patients and family members. This will enable a broad understanding of the nursing staff's contribution to interprofessional collaboration. The interprofessional conception of teamwork from the perspective of the nursing staff and the emphasis on interactive dimension, analyzed in this study, are themes that can support professional training and strengthen collaborative practices in hospital settings.

\section{RESUMO}

Objetivo: Compreender as concepções dos profissionais de enfermagem sobre trabalho em equipe e seus elementos constituintes. Método: Pesquisa qualitativa, realizada em hospital oncológico, por meio de entrevista semiestruturada com 21 profissionais de enfermagem. Resultados: Duas concepções emergiram dos relatos, trabalho em equipe circunscrito à enfermagem e trabalho em equipe com colaboração interprofissional, com destaque para dimensão interativa: comunicação, confiança e vínculo, respeito mútuo e reconhecimento do trabalho do outro, colaboração e conflito. Esta última subcategoria foi apontada como obstáculo para o trabalho em equipe. Conclusão: A enfermagem concebe majoritariamente o trabalho em equipe como ação interprofissional, e isto decorre da qualidade da interação entre os profissionais das diferentes áreas e o reconhecimento e manejo de conflitos.

\section{DESCRITORES}

Enfermagem; Trabalho; Equipe de Enfermagem; Relações Interprofissionais.

\section{RESUMEN}

Objetivo: Comprender las concepciones de los profesionales de enfermería acerca del trabajo en equipo y sus elementos constituyentes. Método: Investigación cualitativa, realizada en hospital oncológico, por medio de entrevista semiestructurada con 21 profesionales de enfermería. Resultados: Dos concepciones emergieron de los relatos, trabajo en equipo circunscrito a la enfermería y trabajo en equipo con colaboración interprofesional, con énfasis para la dimensión interactiva: comunicación, confianza y vínculo, respeto mutuo y reconocimiento del trabajo del otro, colaboración y conflicto. Esta última subcategoría fue señalada como obstáculo para el trabajo en equipo. Conclusión: La enfermería concibe mayoritariamente el trabajo en equipo como acción interprofesional, y eso es consecuente de la calidad de interacción entre los profesionales de las distintas áreas y el reconocimiento y manejo de conflictos.

\section{DESCRIPTORES}

Enfermería; Trabajo; Grupo de Enfermería; Relaciones Interprofesionales.

\section{REFERENCES}

1. Peduzzi M, Norman IJ, Germani ACCG, Silva JAM, Souza GC. Interprofessional education: training for healthcare professionals for teamwork focusing on users. Rev Esc Enferm USP [Internet]. 2013 [cited 2016 Jan 18];47(4):977-83. Available from: http://www.scielo.br/ pdf/reeusp/v47n4/en_0080-6234-reeusp-47-4-0977.pdf

2. Brandt B, Lutfiyya MN, King JA, Chioreso C. A scoping review of interprofessional collaborative practice and education using the lens of Triple Aim. J Interprof Care. 2014;28(5):393-9.

3. Zwarenstein M, Goldman J, Reeves S. Interprofessional collaboration: effects of practice-based interventions on professional practice and healthcare outcomes. Cochrane Database Syst Rev. 2009;(3):CD000072.

4. Morgan S, Pullon S, McKinlay E. Observation of interprofessional collaborative practice in primary care teams: an integrative literature review. Int J Nurs Stud. 2015;52(7):1217-30.

5. Adams TL, Orchard C, Houghton P, Ogrin R. The metamorphosis of a collaborative team: from creation to operation. J Interprof Care. 2014;28(4):339-44.

6. Hart C. The elephant in the room: nursing and nursing power on an interprofessional team. J Contin Educ Nurs. 2015;46(8):349-55.

7. West MA, Lyubovnikova J. Illusions of teamwork in healthcare. J Health Organ Manag. 2013;27(1):134-42.

8. Peduzzi M, Ciampone MHT. Trabalho em equipe e processo grupal. In: Kurcgant P, coordenadora. Gerenciamento em enfermagem. $2^{\mathrm{a}}$ ed. Rio de Janeiro: Guanabara Koogan; 2010. p. 105-20.

9. Lorenzetti J, Oro J, Matos E, Gelbcke FL. Organização do trabalho da enfermagem hospitalar: abordagens na literatura. Texto Contexto Enferm. 2014;23(4):1104-12.

10. Carvalho BG, Peduzzi M, Mandú ENT, Ayres JRCM. Work and Inter-subjectivity: a theoretical reflection on its dialectics in the field of health and nursing. Rev Lat Am Enfermagem [Internet]. 2012 [cited 2016 Jan 10];20(1):19-26. Available from: http://www.scielo.br/pdf/ rlae/v20n1/04.pdf

11. Habermas J. Consciência moral e agir comunicativo. $2^{\text {a }}$ ed. Rio de Janeiro: Tempo Brasileiro; 2003.

12. Honneth A. Luta por reconhecimento: a gramática moral dos conflitos sociais. São Paulo: Editora 34; 2003.

13. Miranda L, Rivera FJU, Artmann E. Trabalho em equipe interdisciplinar de saúde como um espaço de reconhecimento: contribuições da teoria de Axel Honneth. Physis Rev Saúde Coletiva. 2012;22(4):1563-83.

14. Carvalho BG, Peduzzi M, Ayres JRCM. Concepções e tipologia de conflitos entre trabalhadores e gerentes no contexto da atenção básica no Sistema Único de Saúde (SUS). Cad Saúde Pública. 2014;30(7):1453-62.

15. Minayo MCS. Análise qualitativa: teoria, passos e fidedignidade. Ciênc Saúde Coletiva [Internet]. 2012 [citado 2015 dez. 08];17(3):62126. Disponível em: 
16. Kaplan CD, Korf D, Sterk C. Temporal and social contexts of heroin-using populations: an illustration of the snowball sampling technique. J Nerv Ment Dis. 1987;175(9):566-74.

17. Tong A, Sainsbury P, Craig J. Consolidated criteria for reporting qualitative research (COREQ): a 32-item checklist for interviews and focus groups. Int J Qual Health Care. 2007;19(6):349-57.

18. Bardin L. Análise de conteúdo. Lisboa: Edições 70; 2009.

19. Orchard CA. Persistent isolationist or collaborator? The nurse's role in interprofessional collaborative practice. J Nurs Manag. 2010;18(3):248-57.

20. Canadian Interprofessional Health Collaborative (CIHC). Interprofessional education \& core competencies. Canada: University of British Columbia; 2010.

21. Propp KM, Apker J, Ford WSZ, Wallace N, Serbenski M, Hofmeister N. Meeting the complex needs of the health care team: identification of nurse-team communication practices perceived to enhance patient outcomes. Qual Health Res. 2010;20(1):15-28.

22. Peduzzi M, Oliveira MAC, Silva JAM, Agreli HLF, Miranda Neto MV. Trabalho em equipe, prática e educação interprofissional. In: Martins MA, Carrilho FJ, Alves VAF, Castilho EA, Cerri GG, editores. Clínica médica. 2ª ed. Barueri: Manole; 2016. p.171-9.

23. Baindridge L, Nasmith L, Orchard C. Wood V. Competencies for interprofessional collaboration. J Phys Ther Educ. 2010;24(1):6-11.

24. Matos E, Pires DEP, Campos GWS. Relações de trabalho em equipes interdisciplinares: contribuições para novas formas de organização do trabalho em saúde. Rev Bras Enferm [Internet]. 2010 [citado 2016 maio 30];63(5):863-9. Disponível em: http://www.scielo.br/pdf/ reben/v62n6/a10v62n6.pdf

25. Suter E, Arndt J, Arthur N, Parboosingh J, Taylor E, Deutschlander S. Role understanding and effective communication as core competencies for collaborative practice. J Interprof Care. 2009;23(1):41-51. 